\title{
Jean-Jacques LEMAIRE
}

\section{Textbook on MRI \\ Mapping of the Human Deep Brain}

Maps and Extended 3D Analysis 
All Illustrations (C) Jean-Jacques Lemaire

Printed in France

EDP Sciences - ISBN(print): 978-2-7598-2575-2 - ISBN(ebook): 978-2-7598-2576-9

DOI: $10.1051 / 978-2-7598-2575-2$

All rights relative to translation, adaptation and reproduction by any means whatsoever are reserved, worldwide. In accordance with the terms of paragraphs 2 and 3 of Article 41 of the French Act dated March 11, 1957, "copies or reproductions reserved strictly for private use and not intended for collective use" and, on the other hand, analyses and short quotations for example or illustrative purposes, are allowed. Otherwise, "any representation or reproduction - whether in full or in part - without the consent of the author or of his successors or assigns, is unlawful" (Article 40, paragraph 1). Any representation or reproduction, by any means whatsoever, will therefore be deemed an infringement of copyright punishable under Articles 425 and following of the French Penal Code.

(C) Science Press, EDP Sciences, 2021 